\title{
Airway Cell Composition at Rest and after an All-out Test in Competitive Rowers
}

\author{
GIUSEPPE MORICI ${ }^{1,3}$, MARIA R. BONSIGNORE ${ }^{2,3}$, DANIELE ZANGLA $^{1}$, LOREDANA RICCOBONO $^{3}$, \\ MIRELLA PROFITA ${ }^{3}$, ANNA BONANNO ${ }^{3}$, ALESSANDRA PATERNO ${ }^{3}$, ROSSANA DI GIORGI $^{3}$, \\ FRANCO MIRABELLA ${ }^{3}$, LAURA CHIMENTI ${ }^{3}$, ARCANGELO BENIGNO ${ }^{1}$, ANTONIO M. VIGNOLA ${ }^{2,3}$, \\ VINCENZO BELLIA ${ }^{2}$, GIUSEPPE AMATO ${ }^{1}$, and GIOVANNI BONSIGNORE ${ }^{3}$ \\ ${ }^{1}$ Department of Experimental Medicine and ${ }^{2}$ Institute of Medicine and Pneumology, University of Palermo, ITALY; and \\ ${ }^{3}$ Institute of Biomedicine and Molecular Immunology (IBIM), Italian National Research Council (CNR), Palermo, ITALY
}

\begin{abstract}
MORICI, G., M. R. BONSIGNORE, D. ZANGLA, L. RICCOBONO, M. PROFITA, A. BONANNO, A. PATERNÒ, R. DI GIORGI, F. MiRABELlA, L. CHIMENTI, A. BENIGNO, A. M. VIGNOLA, V. BELliA, G. AMATO, and G. BONSIGNORE. Airway Cell Composition at Rest and after an All-out Test in Competitive Rowers. Med. Sci. Sports Exerc., Vol. 36, No. 10, pp. 1723-1729, 2004. Purposes: This study was designed to assess: a) whether rowing affects airway cell composition, and b) the possible relationship between the degree of ventilation during exercise and airway cells. Subjects and Methods: In nine young, nonasthmatic competitive rowers (mean age $\pm \mathrm{SD}: 16.2 \pm 1.0 \mathrm{yr}$ ), induced sputum samples were obtained at rest and shortly after an all-out rowing test over $1000 \mathrm{~m}$ (mean duration: $200 \pm 14 \mathrm{~s}$ ), during which ventilatory and metabolic variables were recorded breath-by-breath (Cosmed K4b, Italy). Results: At rest, induced sputum showed prevalence of neutrophils (60\%) over macrophages (40\%); after exercise, total cell and bronchial epithelial cell (BEC) counts tended to increase. In the last minute of exercise, mean $\dot{V} E$ was $158.0 \pm 41.5 \mathrm{~L} \cdot \mathrm{min}^{-1}$, and $\dot{\mathrm{V}} \mathrm{O}_{2} \cdot \mathrm{kg}^{-1} 62 \pm 11 \mathrm{~mL} \cdot \mathrm{min}^{-1}$. Exercise $\dot{\mathrm{V} E}$ correlated directly with postexercise total cell (Spearman $\rho: 0.75, P<0.05$ ) and macrophage $(\rho: 0.82, P<0.05)$ counts. A similar trend was observed for exercise $\dot{\mathrm{V}}$ and changes in BEC counts from baseline to postexercise $(\rho: 0.64, P=0.11)$. Exercise $\dot{V}$ did not correlate with airway neutrophil counts at rest or after exercise. Expression of adhesion molecules by airway neutrophils, macrophages, and eosinophils decreased after the all-out test. Conclusion: Similar to endurance athletes, nonasthmatic competitive rowers showed increased neutrophils in induced sputum compared with values found in sedentary subjects. The trend toward increased BEC postexercise possibly reflected the effects of high airflows on airway epithelium. Airway macrophages postexercise were highest in rowers showing the most intense exercise hyperpnea, suggesting early involvement of these cells during exercise. However, the low expression of adhesion molecules by all airway cell types suggests that intense short-lived exercise may be associated with a blunted response of airway cells in nonasthmatic well-trained rowers. Key Words: ATHLETES, ALL-OUT ROWING, AIRWAY MACROPHAGE, BRONCHIAL EPITHELIAL CELL, AIRWAY NEUTROPHIL, ADHESION MOLECULES
\end{abstract}

$\mathrm{S}$ tudies on airway cells in well-trained endurance athletes at rest have found evidence of airway inflammation. Increased neutrophils, eosinophils, and lymphocytes, alone or in combination, were reported in the airways of runners (3), swimmers $(4,14)$, ice hockey players (18), and skiers (17). Such variability likely reflects the response to both exercise and environmental factors, as exercise hyperpnea would magnify the effects of exposure to cold and dry air in winter sports $(7,17,18)$, allergens and pollutants in long distance runners (15), or irritants in swimmers $(4,14)$. The effects of exercise at competitive level

\footnotetext{
Address for correspondence: Prof. Maria R. Bonsignore, M.D., Institute of Medicine and Pneumology, University of Palermo, c/o Ospedale Cervello, Via Trabucco, 180, 90146, Palermo, Italy; E-mail: marisa@ibim.cnr.it. Submitted for publication February 2004.

Accepted for publication June 2004.
}

0195-9131/04/3610-1723

MEDICINE \& SCIENCE IN SPORTS \& EXERCISE E $_{\circledast}$

Copyright (C) 2004 by the American College of Sports Medicine

DOI: $10.1249 / 01 . M S S .0000142411 .27685 .72$ seem to be reversible, as the increase in airway inflammatory cells returned toward normal upon cessation of training (16). Similarly, airway inflammation subsided after some days of no airway exposure to cold and dry air in a dog model (9).

The clinical relevance of the changes in airway cells found in athletes is unclear. Some studies in athletes found that airway inflammation and asthma symptoms evolved in parallel (16), whereas other studies pointed out that the occurrence of airway inflammation in athletes was not necessarily associated with symptoms of asthma or presence of bronchial hyperresponsiveness $(4,17,18)$. Most studies, however, obtained airway cell samples in athletes at rest.

More recently, the effects of acute exercise on airway cells have been analyzed. Increased (3) or unchanged (4) neutrophil counts compared with baseline have been documented in nonasthmatic endurance athletes after competitions. To our knowledge, no study has examined airway cells in rowers. Rowing is an ideal model to assess the effects of very intense, short-lived exercise, as it involves a large muscle mass, causes intense hyperpnea (26), and may allow to analyze the relationship between the level of ven- 
tilation during acute exercise and airway cell composition postexercise in human athletes. In horses, bronchial epithelial damage was documented after intense exercise while breathing cold air (8), but ventilation was not measured. Studies in dogs, in which peripheral airways were exposed to dry or wet air challenge, showed marked mucosal injury upon exposure to dry air (11). No data are available in human athletes on the relationship between exercise ventilation and postexercise airway cell counts or composition.

In this study, induced sputum samples were collected in a group of young competitive rowers at rest and after a short all-out rowing test over $1000 \mathrm{~m}$ (duration: about $3 \mathrm{~min}$ ) conducted in the laboratory under standard environmental conditions. As in our previous studies $(3,4)$, resting samples, obtained a few days before exercise samples, were considered as mostly influenced by the chronic effects of habitual training. Instead, samples obtained after exercise were considered to reflect the effects of acute exercise.

\section{METHODS}

Subjects. Nine ( 8 male, 1 female) junior competitive rowers were studied (mean age \pm SD: $16.2 \pm 1.0 \mathrm{yr}$; body weight: $71.3 \pm 8.4 \mathrm{~kg}$; height: $174.3 \pm 8.6 \mathrm{~cm}$ ). Mean fat mass (plicometry) was $13.4 \pm 3.6 \%$ of body weight. No subject referred a history of atopy or asthma, exerciseinduced respiratory symptoms, or habitual or on-demand use of inhaled beta-2-agonists. All subjects were nonsmokers. None referred recent infection, other significant disease, or use of steroidal/nonsteroidal anti-inflammatory agents before or during the study.

The study protocol was approved by the Ethical Committee of the University of Palermo, and the athletes, or their parents in case of minors, gave written informed consent.

Experimental protocol. Subjects were tested in February-March 2001, during a precompetition training period. Besides rowing, the training program included running and weight lifting. Average rowing volume was 65-95 $\mathrm{km} \cdot \mathrm{wk}^{-1}$. Rowing intensity during training was as follows: $8-10 \%$ of training was at a maximal speed, $25-30 \%$ at $80-90 \%$, and the remaining at $65-80 \%$ of maximal speed.

Each subject underwent clinical assessment, spirometry, and collection of induced sputum at rest, at least $24 \mathrm{~h}$ after a training session.

Exercise data were collected on average $2.4 \mathrm{~d}$ after the baseline study (range: 1-4 d) (23). Each athlete underwent an all-out test at the rowing ergometer (Concept II, Morrisville, VT) over a distance of $1000 \mathrm{~m}$, after which an induced sputum sample was collected. Environmental conditions in the laboratory during the tests were: barometric pressure $747 \pm 6 \mathrm{~mm} \mathrm{Hg}$, ambient temperature $23 \pm 1^{\circ} \mathrm{C}$, humidity $50 \pm 7 \%$.

The rowing test was preceded by a 20-min warm-up. After 10 min of low intensity exercise (heart rate: 140-160 bpm, 22-26 strokes $\cdot \mathrm{min}^{-1}$ ), the subject did two to three sprints of five to seven strokes at submaximal intensity (28-32 strokes $\cdot \mathrm{min}^{-1}$ ). Active rest ( $2 \mathrm{~min}$ of light rowing, 22-24 strokes $\cdot \min ^{-1}$ ) was maintained between sprints. The warm-up ended with a few start trials at maximal intensity preceded and followed by short active rest periods. Warm-up was followed by 10 min of recovery during which the equipment was mounted and checked.

Physiological variables during exercise were continuously recorded breath-by-breath. Portable equipment (K4b, Cosmed, Italy) was used because of its limited weight and no interference with rowing movements. During tests, subjects were wearing a neoprene mask holding a support for the gas sampling line and pneumotachograph.

The induced sputum sample was collected within $1 \mathrm{~h}$ of the end of the all-out effort in all subjects.

Induced sputum production and processing. Sputum induction and processing were according to the method of Fahy and coworkers (10), with slight modifications $(3,4,27)$. Subjects were exposed to hypertonic saline (3\%) aerosol for 20-min (ultrasonic nebulizer Fisoneb, Fisons Italchimici Spa, Rome, Italy; median particle diameter: $2.5 \mu \mathrm{m}$, output: $1 \mathrm{~mL} \cdot \mathrm{min}^{-1}$ ), and expectorated into sterile ampoules. Samples were added an equal volume of $0.1 \%$ dithiothreitol saline solution (Sigma Chemical Co., St. Louis, MO), gently mixed, placed in a water bath at $37^{\circ} \mathrm{C}$ for $15 \mathrm{~min}$, and centrifuged at $800 \times g$ for $10 \mathrm{~min}$. Supernatants were frozen at $-20^{\circ} \mathrm{C}$. Cell pellets were resuspended in saline, and total cell count (standard hemocytometer) and viability (Trypan blue exclusion) assessed in $10-\mu \mathrm{L}$ aliquots. The cells were cytocentrifuged (Cytospin 2, Shandon Instruments, Runcorn, UK) and stained (Diff Quick, Merz-Dade, Dudingen, Switzerland). Slides were blindly read by two investigators (LR, AMV) who counted at least 400 cells per slide $(K=0.93)$. Differential counts were expressed as corrected percentages, after subtraction of squamous cells. Samples were considered adequate if sputum volume was $\geq 1 \mathrm{~mL}$.

Expression of adhesion molecules on cells in induced sputum. Cell pellets of induced sputum were resuspended in saline. Slides were prepared, dried, fixed (acetone/methanol, $4^{\circ} \mathrm{C}, 10 \mathrm{~min}$ ), and incubated $\left(37^{\circ} \mathrm{C}, 1 \mathrm{~h}\right.$ ) with monoclonal antibodies (DAKO A/S, Denmark) anti-Lselectin, CD11a/CD18 (LFA-1), and CD11b/CD18 (MAC-1) at the dilutions of 1:2, 1:100, and 1:100, respectively. Immunoreactivity was revealed by the labeled streptavidin biotin (LSAB) alkaline-phosphatase technique. Two investigators (MP and AMV) counted 400 cells per slide (K: 0.95). Results were expressed as percentage of positive cells.

Sputum supernatants were analyzed to determine the concentrations of: a) albumin, as a marker of increased permeability (nephelometric assay, Beckman Array Protein System, detection threshold $6.0 \mu \mathrm{g} \cdot \mathrm{mL}^{-1}$ ) using specific monoclonal antibodies (Beckman Immunochemistry Systems); and b) neutrophil elastase, as a marker of neutrophil activation (enzyme immunoassay, detection threshold: 20 $\mu \mathrm{g} \cdot \mathrm{L}^{-1}$; Ecoline, Kit Merck, Darmstadt, Germany).

Statistics. Data are reported as means and standard deviation, except for induced sputum cell counts reported as median and interquartile range (IQR). Respiratory variables 


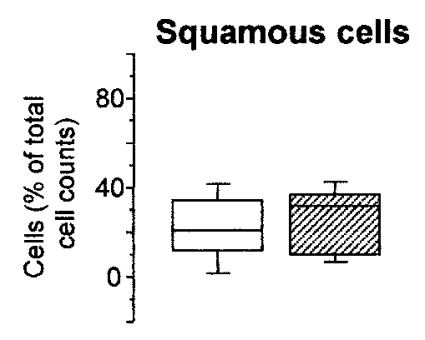

Macrophages

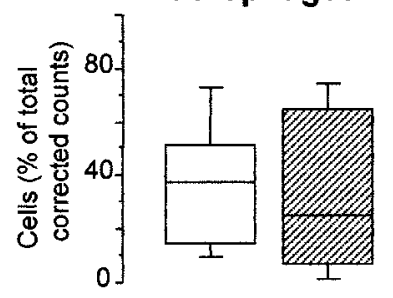

Neutrophils
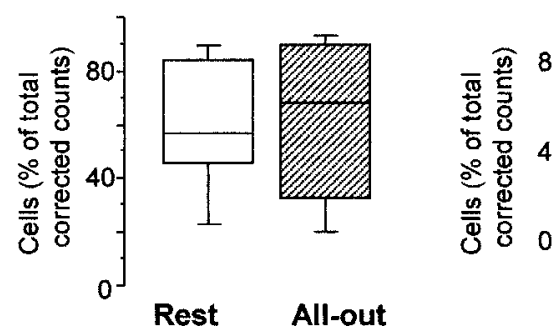

Lymphocytes

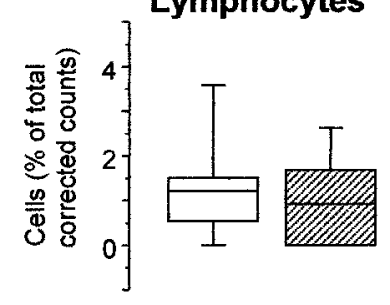

Eosinophils

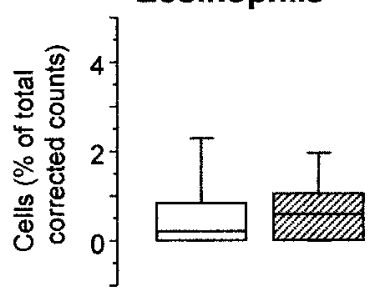

Bronchial Epithelial Cells

FIGURE 1-Box plots of induced sputum cell composition at rest (white), and after the all-out test (shaded)

are reported as the average of all measurements in the last minute of exercise.

Comparisons between rest and exercise were by paired $t$-test or Wilcoxon signed rank test. Analysis of Type II error (power of the test: 0.90; two-tailed comparison) was done when differences between group means were of borderline significance, in order to estimate the number of observations necessary to reach significance, assuming mean and standard deviation of the groups to remain the same after increasing $N$. To assess whether exercise hyperpnea affected airway cells, the relationships between $\dot{V E}$ normalized for body weight or its components $(\mathrm{Vt}, \mathrm{f})$ and cell counts were analyzed by Spearman rank correlation (Statview 4.5 software). In addition, the same analyses were repeated by using the change in cell counts (postexercise minus rest). Statistical significance was at $P<0.05$ in all tests.

\section{RESULTS}

Rest. Mean FEV1 and FVC were $4.39 \pm 0.89 \mathrm{~L}$ (106 \pm $14 \%$ predicted $)$ and $5.48 \pm 1.19 \mathrm{~L}(120 \pm 20 \%$ predicted $)$, respectively. FEV1/FVC was $0.81 \pm 0.05 \%$.
Mean total corrected cell counts in induced sputum were in the normal range (median: $1.97 \times 10^{6}$ cells $\cdot \mathrm{mL}^{-1}$, IQR: $4.81 \times 10^{6}$ cells $\left.\cdot \mathrm{mL}^{-1}\right)$. Such large variability was accounted for by two subjects, otherwise similar to other athletes (no respiratory symptoms or history of asthma, similar differential airway cell counts), who showed total cell counts of $12 \times 10^{6}$ and $16 \times 10^{6}$ cells $\cdot \mathrm{mL}^{-1}$, respectively. Macrophages and neutrophils were $38.0 \pm 23.9 \%$ and $59.6 \pm 25.1 \%$ of total corrected cells, respectively. Differential and absolute counts for lymphocytes, eosinophils and bronchial epithelial cells were in the normal range (Fig. 1, Table 1).

All-out test. The athletes performed at their best, and mean test duration and workload were $200 \pm 14 \mathrm{~s}$ and 360 $\pm 76 \mathrm{~W}$, respectively. No respiratory or other complaint was recorded in any subject during or after exercise. During the last minute of the all-out test mean $\dot{\mathrm{VO}}_{2}$ and $\mathrm{VCO}_{2}$ were $4.72 \pm 0.91$ and $5.24 \pm 1.17 \mathrm{~L} \cdot \mathrm{min}^{-1}$, respectively, and respiratory exchange ratio $\left(\dot{\mathrm{VCO}}_{2} / \mathrm{V}_{2}, \mathrm{RER}\right)$ was $1.15 \pm$ 0.16. Data normalized for body weight were: $\mathrm{VO}_{2}: 62 \pm 11$ $\mathrm{mL} \cdot \mathrm{min}^{-1} \cdot \mathrm{kg}^{-1} ; \dot{\mathrm{VE}}: 2.19 \pm 0.41 \mathrm{~L} \cdot \mathrm{min}^{-1} \cdot \mathrm{kg}^{-1}, \mathrm{Vt}: 31.0$ $\pm 5.1 \mathrm{~mL} \cdot \mathrm{kg}^{-1}$. The high respiratory rate $(71.7 \pm 4.2)$ was due to entrainment of breathing to stroke rate $(37.8 \pm 1.6$ strokes $\cdot \mathrm{min}^{-1}$, range $35-40$ ) (26). Inspiratory and expiratory times during exercise were $0.42 \pm 0.03$ and $0.42 \pm$ $0.03 \mathrm{~s}$.

Cell viability did not differ between rest $(81 \pm 12 \%)$ and postexercise (72 $\pm 8 \%$, NS) samples. Airway cell composition postexercise did not change significantly compared with resting conditions (Fig. 1, and Table 1), even after excluding the two subjects with high sputum cellularity at rest. In these two subjects, postexercise airway cell counts were similar to those found in the rest of the group. There was a trend for bronchial epithelial cells to increase post exercise $(P=0.12$ by Wilcoxon test), and Type II error analysis showed that such trend would reach significance if the sample size were increased to 10 or 11 subjects.

In induced sputum supernatants, the concentration of albumin (rest: $8.4 \pm 15.4$; all-out test $44.5 \pm 96.3 \mathrm{mg} \%$ ) and total neutrophil elastase (rest: $181 \pm 141$; all-out test $317 \pm$ $287 \mu \mathrm{g} \cdot \mathrm{L}^{-1}$ ) tended to increase postexercise.

Relationships between exercise hyperpnea and airway cells. Because total cell counts in induced sputum tended to increase after all-out tests whereas differential counts were unaffected, we analyzed the relationships between exercise VE and absolute cell counts. Postexercise total corrected cell counts were highest in athletes showing the highest $\mathrm{VE}$ per kilogram $(\rho: 0.75, P<0.05)$ and $\mathrm{Vt}$ per kilogram $(\rho: 0.68, P=0.05)$ during exercise, whereas no correlation was found for $\mathrm{f}$. Postexercise macrophage counts in induced sputum correlated with both VंE per kilogram $(\rho$ :

TABLE 1. All-out test $(N=9)$ : absolute corrected cell counts in induced sputum.

\begin{tabular}{|c|c|c|c|c|c|c|}
\hline Condition & Total cells $\left(10^{6} \cdot \mathrm{mL}^{-1}\right)$ & $\mathrm{M}\left(10^{4} \cdot \mathrm{mL}^{-1}\right)$ & PMN $\left(10^{4} \cdot \mathrm{mL}^{-1}\right)$ & $\operatorname{Eos}\left(10^{4} \cdot \mathrm{mL}^{-1}\right)$ & Lymph $\left(10^{4} \cdot \mathrm{mL}^{-1}\right)$ & BEC $\left(10^{4} \cdot \mathrm{mL}^{-1}\right)$ \\
\hline $\begin{array}{l}\text { Rest } \\
\text { All-out }\end{array}$ & $\begin{array}{l}1.97(4.81) \\
2.47(1.53)\end{array}$ & $\begin{array}{l}86(94) \\
47(95)\end{array}$ & $\begin{array}{l}128(356) \\
153(178)\end{array}$ & $\begin{array}{l}0.5(2.6) \\
1.4(2.1)\end{array}$ & $\begin{array}{l}3(10) \\
2(3)\end{array}$ & $\begin{array}{l}0.0(1.7) \\
2.4(12.2)\end{array}$ \\
\hline
\end{tabular}

Cell counts are reported as median (interquartile range). M, macrophage; PMN, polymorphonuclear neutrophils; Eos, eosinophils; Lymph, lymphocytes; BEC, bronchial epithelial cells. All comparisons between experimental conditions were NS. BEC showed a trend $(P=0.12)$ to increase postexercise. 
$0.82, P<0.05)$ and $\mathrm{Vt} \cdot \mathrm{kg}^{-1}(\rho: 0.93, P=0.01)$. Neutrophil, eosinophil, or lymphocyte counts did not show any relationship with exercise ventilation.

Figure 2 reports the relationships between changes in airway cells postexercise and exercise $\dot{V} E$ in seven rowers, after excluding both subjects with high cell counts in induced sputum at rest. Bronchial epithelial cells showed a trend to increase postexercise as $\dot{V E}$ increased. No correlation was found between ventilatory variables recorded during exercise and airway cell counts at baseline.

Adhesion molecules. Expression of L-selectin by airway neutrophils and macrophages decreased after the all-out
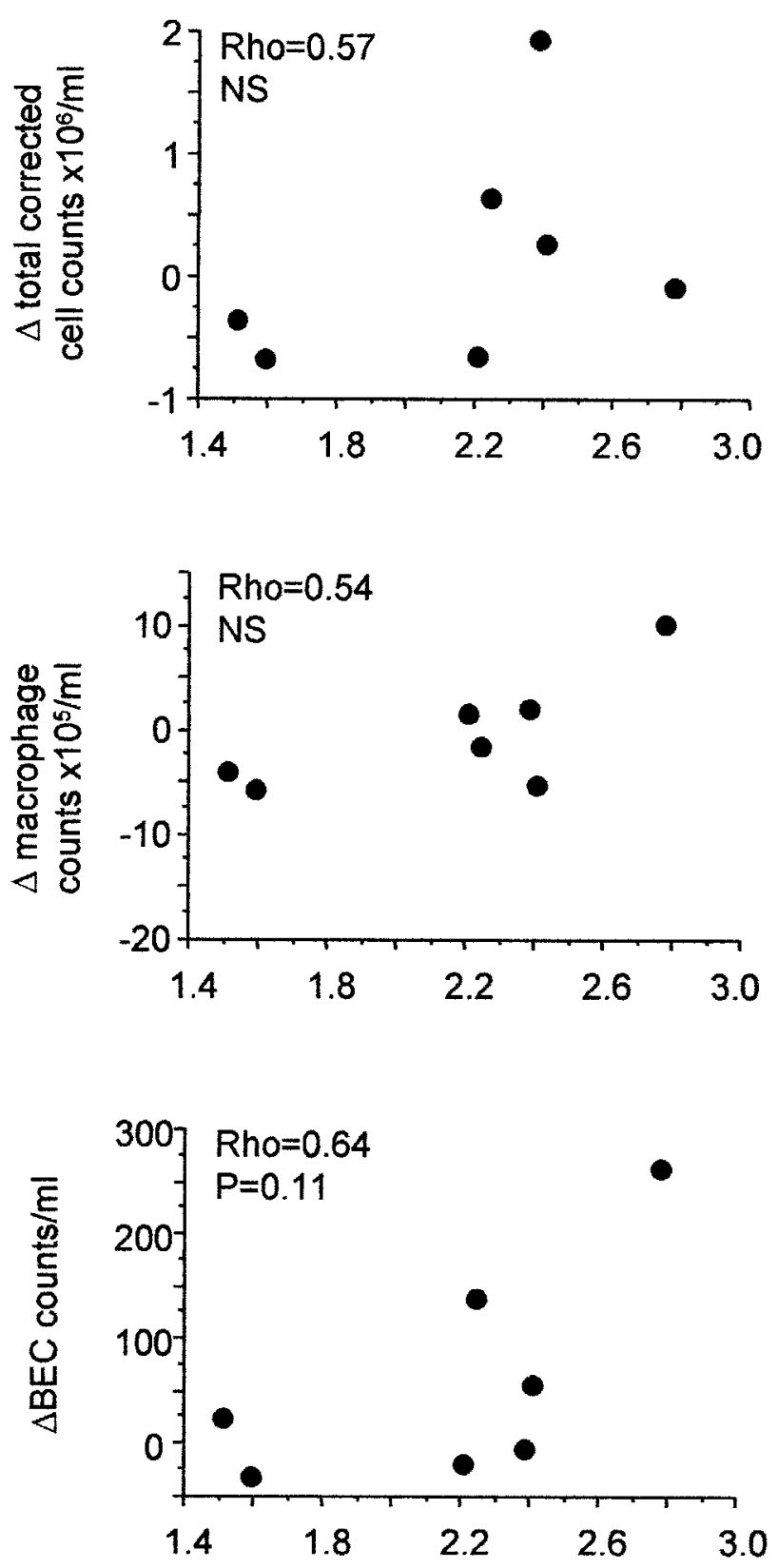

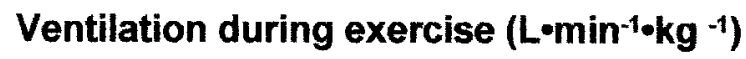

FIGURE 2-Relationship between $\dot{V} E$ during exercise and changes in total cell (upper panel), macrophage (middle panel) and bronchial epithelial cell (lower panel) absolute counts in induced sputum. rowing test (Fig. 3). Macrophages in induced sputum also showed decreased expression of LFA-1, whereas eosinophils showed decreased MAC-1 expression postexercise. No correlation was found between expression of adhesion molecules and airway cell counts after exercise.

\section{DISCUSSION}

We studied the effects of training and short-lived intense exercise on airway cells in a sample of young, well-trained competitive rowers. Similar to data obtained in athletes of other sports, induced sputum of rowers at rest was rich in neutrophils, and did not change significantly postexercise except for a trend toward increased bronchial epithelial cells. Total cell counts in induced sputum postexercise were highest in those athletes who showed the highest hyperpnea during the all-out test, this effect being accounted for by macrophages and epithelial cells, as neutrophils, eosinophils, or lymphocytes did not correlate with any ventilatory variable recorded during exercise. Finally, expression of adhesion molecules by airway cells decreased after the all-out test.

Our previous data on airway cells in endurance athletes $(3,4)$ were obtained after competitions, i.e., under experimental conditions not allowing measurements of physiological variables during exercise. In this study, we wished to assess whether airway cells showed any modulation related to the level of exercise hyperpnea; for this purpose, we chose to study rowers since they are trained to perform very intense exercise of limited duration, and there are no data on airway cells in these athletes. The subjects studied were young and not asthmatic, and habitually underwent all-out tests during training.

The major limitation of our study is the small sample size. Our initial group of rowers included 15 athletes from the same team, but over a third of them were unable to produce adequate sputum samples. In addition, the known effects of repeated sputum induction on airway cells (23) prevented obtaining samples at rest and postexercise on the same day. The difficulty in obtaining induced sputum samples in healthy subjects, together with the inherent variability in cell and biochemical measurements in induced sputum samples, are the most likely explanation for the limited statistical significance of our findings.

Despite these limitations, cell composition of induced sputum in rowers at rest was similar to that previously found in endurance athletes $(3,4)$, in agreement with the view that airway neutrophil differential counts are increased in welltrained compared with sedentary subjects. At rest, neutrophils accounted for about $60 \%$ of cells in induced sputum of swimmers $(4,13)$, for $78 \%$ of cells in runners (3), and for $81 \%$ in elite ice hockey players (18). Increased airway neutrophils were also found in bronchial biopsies of skiers (17). Conversely, mean neutrophil differential counts in induced sputum ranged from $27 \pm 13 \%$ (25) to $37 \%$ (2) in large series of healthy subjects. Lumme and coworkers (18) reported that neutrophils accounted for $30 \%$ of cells in sedentary subjects. Thus, the data obtained in well-trained 


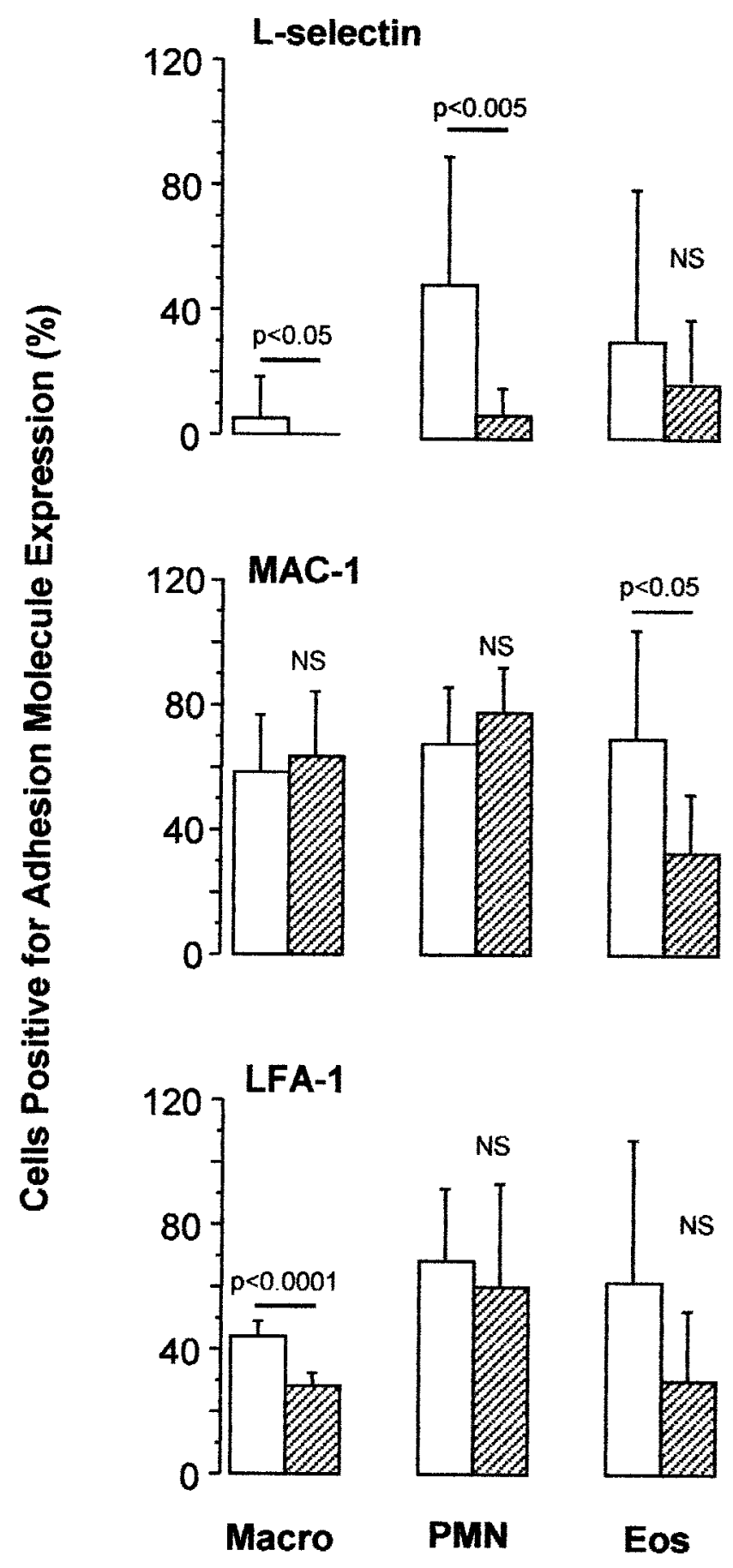

FIGURE 3-Expression of adhesion molecules by airway cells (bar fillings as in Figs. 1 and 2). Lines and figures over bars report significant differences and $P$ values, respectively.

young rowers were comparable to those reported by studies on athletes of other disciplines and showed predominance of neutrophils in induced sputum at rest.

Total or differential airway cell counts did not change significantly after the all-out test. Only bronchial epithelial cells (BEC) tended to increase after exercise, and their change correlated with exercise $\dot{V E}$. The mild changes we observed compared with the severe epithelial damage found in dogs and horses after exercise in cold weather $(7,8)$ are likely explained by different experimental settings, as our tests were conducted in the laboratory under standard environmental conditions.

Our study was not designed to address the pathogenetic mechanism(s) responsible for exercise-induced airway changes, that is, hyperosmolarity of airway surface lining (1) or cooling-rewarming of bronchial wall (20). Intense exercise hyperpnea can affect airway epithelium by causing changes in viscosity, tonicity, or amount of the airway lining fluid, as previously suggested (1). The increase in BEC in induced sputum led us to consider the possibility that high airflows during all-out exercise may cause epithelial damage through shear stress on the airway wall. In favor of such hypothesis, we recorded much higher $\mathrm{Vt}$ and respiratory rate in our athletes compared with the figures used in recent calculations of shear stress along the bronchial tree in the human lung (21). In addition, maximal rowing was reported to be associated with inhomogeneous ventilation (12), supporting the possibility of increased shear stress in the airways during supramaximal exercise. On the other hand, exercise bronchodilatation (6) can be expected to lower airway resistance and shear stress in the airways considerably, and experimental data obtained in dogs argue against a major role of shear stress as a cause of airway epithelial damage (11). The exact mechanism(s) of hyperpnea-induced increase in BEC counts, and the possible role of airway shear stress, remain unclear and deserve further study.

$\dot{V} E$ during exercise resulted positively correlated to total cell and macrophage counts postexercise. This result may appear in contrast with the lack of change in cell counts from rest to postexercise conditions. However, it is impossible to obtain true "resting" samples in athletes on regular intense training, as according to experimental data, airway inflammation may still be present $24 \mathrm{~h}$ after dry air challenge in the dog (22). Our results suggest that, besides BEC, the airway macrophage might be the cell type mostly affected by intense and short-lived exercise in well-trained subject. Alternatively, intense hyperpnea during exercise could mechanically facilitate macrophage detachment from airway wall. More studies are needed to further investigate on the response of airway macrophages to exercise in humans.

We found no change in neutrophil counts in induced sputum or elastase concentration in sputum supernatants postexercise and no evidence of their modulation by the level of exercise $\dot{V E}$. It is likely that the all-out test was too short in duration to cause neutrophil influx into the airways, as increased airway neutrophils in induced sputum were only found after very prolonged exercise, i.e., a marathon race (3). Alternatively, we may have missed the increase of airway neutrophils as induced sputum samples were collected shortly after exercise. Airway neutrophils increased about $2 \mathrm{~h}$ after dry air challenge in the dog (22). Finally, neutrophil mobilization in peripheral blood was trivial after the all-out test (data not shown), yielding another potential explanation for the lack of a neutrophil response in the airways (3). 
The most intriguing finding of this study was the decreased expression of L-selectin by neutrophils and macrophages in induced sputum after all-out rowing, similar to data previously obtained in runners (3) and swimmers (4) after prolonged exercise. Thus, intense exercise may mostly cause acute functional changes in airway cells, and the experiments in rowers extend previous observations by showing that changes in adhesion molecules may require a short exercise time to develop.

We have proposed that reduced expression of adhesion molecules may play some role in modulating airway inflammation in athletes (5). On one hand, activation of bronchial epithelial cells by hyperosmolarity or cooling-rewarming caused release of chemotactic factors, like interleukin 8 or RANTES (13). On the other hand, shedding of L-selectin upon exposure of neutrophils to a hypertonic medium inhibited neutrophil activation (24), and neutrophils expressing low L-selectin levels were found to undergo apoptosis (19). Therefore, the reduction of adhesion molecules could offset the immunostimulatory effects of increased chemotactic expression, possibly accounting for the tight control of inflammatory activation at the airway level in nonasthmatic athletes tested after exercise (5).

Our study shows other limitations besides the small sample size. First, we did not assess the reproducibility of airway cell determinations in rowers at rest or after exercise. Nevertheless, the data were consistent in the group and comparable to previous findings obtained by other authors and our group in endurance athletes, which suggest interpreting exercise neutrophilia as secondary to exercise training. Second, we did not measure bronchial reactivity, or obtain serial spirometric measurements after the tests. This

\section{REFERENCES}

1. Anderson, S. D., and E. Daviskas. The mechanism of exerciseinduced asthma is... . J. Allergy Clin. Immunol. 106:453-459, 2000.

2. Belda, J., R. Leigh, K. Parameswaran, P. M. O’Byrne, M. R. SEARs, and F. E. Hargreave. Induced sputum cell counts in healthy adults. Am. J. Respir. Crit. Care Med. 161:475-478, 2000.

3. Bonsignore, M. R., G. Morici, L. Riccobono, et al. Airway inflammation in nonasthmatic amateur runners. Am. J. Physiol. Lung Cell. Mol. Physiol. 281:L668-L676, 2001.

4. Bonsignore, M. R., G. Morici, L. Riccobono, et al. Airway cells after swimming outdoors or in the sea in non-asthmatic athletes. Med. Sci. Sports Exerc. 35:1146-1152, 2003.

5. Bonsignore, M. R., G. Morici, A. M. Vignola, et al. Airway inflammation in athletes: what does it mean? Clin. Exp. Allergy 33:14-21, 2003.

6. Crimi, E., R. Pellegrino, A. Smeraldi, and V. Brusasco. Exercise-induced bronchodilation in natural and induced asthma: effects on ventilatory response and performance. J. Appl. Physiol. 92:2353-2360, 2002.

7. Davis, M. S., B. McKiernan, S. McCullough, et al. Racing Alaskan sled dogs as a model of "ski asthma." Am. J. Respir. Crit. Care Med. 166:878-882, 2002.

8. Davis, M. S., A. J. Lockard, D. J. Marlin, and A. N. Freed. Airway cooling and mucosal injury during cold weather exercise. Equine Vet. J. Suppl. 34:413-416, 2002.

9. Davis, M. S., B. Schofield, and A. N. Freed. Repeated peripheral airway hyperpnea causes inflammation and remodeling in dogs. Med. Sci. Sports Exerc. 35:608-616, 2003. choice was motivated by: a) the lack of reported exerciseinduced respiratory symptoms in our athletes, and b) the need to start induced sputum collection as soon as possible in order to avoid missing early changes after an exercise test of limited duration. Therefore, the relationship between airway reactivity and inflammation in rowers deserves further study. Lastly, we cannot exclude that the small changes observed might be secondary to the combination of warmup, a necessary step before performing very intense exercise (28), and all-out effort. This possibility seems unlikely as the all-out test started about $10 \mathrm{~min}$ after the end of warmup, and its overall intensity was much higher compared to that of warm-up.

In conclusion, our experiments in rowers suggest that intense training increased neutrophil differential counts in induced sputum at rest. Intense short-lived exercise slightly increased bronchial epithelial cell counts in induced sputum, and such an increase was proportional to the level of exercise hyperpnea. Macrophage counts postexercise also were proportional to $\dot{V} E$ during exercise, suggesting that airway macrophages may be involved in the response to exercise besides airway neutrophils. The low expression of adhesion molecules by airway cells after all-out exercise might indicate early down-regulating mechanisms preventing inflammatory activation in response to exercise in nonasthmatic competitive athletes.

We thank the athletes for their enthusiastic participation in the study, and G. Nucci for helpful discussion of the data. We are indebted to Prof. E. Cillari, Ospedale Cervello, Palermo, for allowing sample processing by the hospital laboratories.

The study was supported by the National Research Council of Italy (CNR). COSMED kindly provided the equipment used for physiological measurements.

10. Fahy, J. V., J. Liu, H. Wong, and H. A. Boushey. Cellular and biochemical analysis of induced sputum from asthmatic and from healthy subjects. Am. Rev. Respir. Dis. 147:1126-1131, 1993.

11. Freed, A. N., C. Omori, B. H. Schofield, and W. Mitzner. Dry air-induced mucosal cell injury and bronchovascular leakage in canine peripheral airways. Am. J. Respir. Cell Mol. Biol. 11:724$732,1994$.

12. Hanel, B., I. Law, and J. Mortensen. Maximal rowing has an acute effect on the blood-gas barrier in elite athletes. J. Appl. Physiol. 95:1076-1082, 2003.

13. Hashimoto, S., Y. Gon, K. Matsumoto, I. Takeshita, S. MaRUOKA, and T. HORIE. Inhalant corticosteroids inhibit hyperosmolarity-induced, and cooling and rewarming-induced interleukin- 8 and RANTES production by human bronchial epithelial cells. Am. J. Respir. Crit. Care Med. 162:1075-1080, 2000.

14. Helenius, I. J., P. Rytilä, M. Metso T. Hahhtela, P. Venge, and H. O. TikKANEN. Respiratory symptoms, bronchial responsiveness, and cellular characteristics of induced sputum in elite swimmers. Allergy 53:346-352, 1998.

15. Helenius, I., and T. HaAhtela. Allergy and asthma in elite summer sport athletes. J. Allergy Clin. Immunol. 106:444-452, 2000.

16. Helenius, I., P. Rytilä, S. Sarna, et al. Effect of continuing or finishing high-level sports on airway inflammation, bronchial hyperresponsiveness, and asthma: a 5-year prospective follow-up study of 42 highly trained swimmers. J. Allergy Clin. Immunol. 109:962-968, 2002.

17. Karjalainen, E. M., A. Laitinen, M. Sue-Chu, A. Altraja, L. BJERMER, and L. A. Laitinen. Evidence of airway inflammation and remodeling in ski athletes with and without bronchial hyper- 
responsiveness to methacholine. Am. J. Respir. Crit. Care Med. 161:2086-2091, 2000.

18. Lumme, A., T. HaAtela, J. ÖunAp, et al. Airway inflammation, bronchial hyperresponsiveness and asthma in elite ice hockey players. Eur. Respir. J. 22:113-117, 2003.

19. Matsuba, K. T., S. F. Van Eeden, S. G. Bicknell, B. A. Walker, S. Hayashi, and J. C. HogG. Apoptosis in circulating PMN: increased susceptibility in L-selectin-deficient PMN. Am. J. Physiol. 272:H2852-H2858, 1997.

20. McFadDEN, E. R., JR. Hypothesis: exercise-induced asthma as a vascular phenomenon. Lancet 335:880-883, 1990.

21. NucCI, G., B. SukI, and K. Lutchen. Modeling airflow-related shear stress during heterogeneous constriction and mechanical ventilation. J. Appl. Physiol. 95:348-356, 2003.

22. Omori, C., B. H. Schofield, W. Mitzner, and A. N. Freed. Hyperpnea with dry air causes time-dependent alterations in mucosal morphology and bronchovascular permeability. J. Appl. Physiol. 78:1043-1051, 1995.

23. Purokivi, M., J. Randell, M. R. Hirvonen, and H. Tukiainen. Reproducibility of measurements of exhaled NO, and cell count and cytokine concentrations in induced sputum. Eur. Respir. J. 16:242-246, 2000.

24. Rizoli, S. B., O. D. Rotstein, J. Parodo, M. J. Phillips, and A. KAPUS. Hypertonic inhibition of exocytosis in neutrophils: central role for osmotic actin skeleton remodeling. Am. J. Physiol. Cell Physiol. 279:C619-C633, 2000.

25. Spanevello, A., M. Confalonieri, F. Sulotto, et al. Induced sputum cellularity: reference values and distribution in normal volunteers. Am. J. Respir. Crit. Care Med. 162:1172-1174, 2000.

26. Steinacker, J. M., M. Both, and B. J. Whipp. Pulmonary mechanics and entrainment of respiration and stroke rate during rowing. Int. J. Sports Med. 14(Suppl. 1):S15-S19, 1993.

27. Vignola, A. M., L. Riccobono, A. Mirabella, et al. Sputum metalloproteinase-9/tissue inhibitor of metalloproteinase-1 ratio correlates with airflow obstruction in asthma and chronic bronchitis. Am. J. Respir. Crit. Care Med. 158:1945-1950, 1998.

28. Volianitis, S., A. K. McConnell, Y. Koutedakis, and D. A. JONES. Specific respiratory warm-up improves rowing performance and exertional dyspnea. Med. Sci. Sports Exerc. 33:11891193, 2001. 